\title{
ETHzürich
}

ETH Library

\section{Cloud Ice Processes Enhance Spatial Scales of Organization in Arctic Stratocumulus}

\section{Journal Article}

Author(s):

Eirund, Gesa K.; Lohmann, Ulrike (D); Possner, Anna

Publication date:

2019-12-16

Permanent link:

https://doi.org/10.3929/ethz-b-000384642

Rights / license:

Creative Commons Attribution 4.0 International

Originally published in:

Geophysical Research Letters 46(23), https://doi.org/10.1029/2019GL084959 


\section{Geophysical Research Letters}

\author{
RESEARCH LETTER \\ 10.1029/2019GL084959 \\ Key Points: \\ - Mixed-phase clouds in the Arctic \\ feature organized open-cell \\ structures, similar to warm-phase \\ stratocumuli \\ - For an ice to liquid water path ratio \\ of $1: 2$, ice processes strengthen cold \\ pools and impact cell size \\ - A reduction of the cloud \\ condensation nuclei concentration \\ also impacts precipitation intensity, \\ cold pool strength, and cell size
}

Supporting Information:

- Supporting Information S1

Correspondence to:

G. K. Eirund,

gesa.eirund@env.ethz.ch

Citation:

Eirund, G. K., Lohmann, U., \&

Possner, A. (2019). Cloud ice processes enhance spatial scales of organization in Arctic stratocumulus. Geophysical Research Letters, 46, 14,109-14,117. https://doi.org/10.1029/2019GL084959

Received 13 AUG 2019

Accepted 29 OCT 2019

Accepted article online 15 NOV 2019

Published online 2 DEC 2019

(C)2019. The Authors.

This is an open access article under the terms of the Creative Commons

Attribution License, which permits use, distribution and reproduction in any medium, provided the original work is properly cited.

\section{Cloud Ice Processes Enhance Spatial Scales of Organization in Arctic Stratocumulus}

\author{
Gesa K. Eirund ${ }^{1}$ (D), Ulrike Lohmann ${ }^{1}$ (D), and Anna Possner ${ }^{2}$ (D) \\ ${ }^{1}$ Institute for Atmospheric and Climate Science, ETH Zurich, Zurich, Switzerland, ${ }^{2}$ Institute for Atmospheric and \\ Environmental Sciences, Goethe-University Frankfurt, Frankfurt, Germany
}

\begin{abstract}
Stratocumulus clouds around the globe tend to organize into cellular patterns, a phenomenon that has been primarily studied for the subtropical trade wind region. However, stratocumulus are also prevalent in high latitudes, where they often occur as mixed-phase clouds. Yet little research has been conducted regarding mechanisms of cloud organization in the mixed-phase regime. In cloud-resolving model simulations we investigate the processes driving organization in open-cell mixed-phase stratocumuli. Similar to warm-phase clouds, mixed-phase clouds develop a subcloud circulation of evaporated/sublimated precipitation, cold pool formation, and consecutive updrafts driving new convective cells. For a larger ice to liquid water ratio, we find locally stronger precipitation and larger cloud cells. Hence, a higher concentration of ice nucleating particles can induce a breakup of the stratocumulus organization, with implications for the radiative balance at the surface. A decrease in cloud condensation nuclei concentration is also found to intensify precipitation and impact cloud organization.
\end{abstract}

Plain Language Summary Low-lying clouds have been found to organize into honeycomb-like spatial patterns. This has been primarily studied for liquid clouds in the subtropical regions but has remained unexplored in the high latitudes. Previous studies focusing on precipitating open-cell clouds have found that below cloud base a continuous cycle of evaporation and subsequent latent cooling, sinking, and lateral spreading of the air mass can be observed. Colliding air masses push the air upward which leads to localized updrafts and new cloud formation. In this study, we explore the organization of open-cell polar clouds, which consist of both liquid cloud droplets and ice crystals (so-called mixed-phase clouds). We show that open-cell mixed-phase clouds also form honeycomb-like spatial patterns following the same mechanism as liquid clouds. However, the spatial extent of cloud patterns changes with the amount of cloud ice. Clouds that contain ice produce precipitation earlier and more intensively. As a result, the cooling below cloud base is strengthened and the cloud cells grow larger. This has implications for the radiative balance at the surface. The stronger growth of ice-containing clouds leads to a breakup of the organized structures, which increases the amount of outgoing radiation.

\section{Introduction}

Around the globe, boundary layer clouds such as shallow cumulus or stratocumulus may organize into different cellular structures (e.g., Wood, 2012). The study of these different cloud morphologies has received growing interest in recent years. It has been shown that cloud organization and transitions between cloud regimes can significantly alter the radiative properties of the entire cloud field (McCoy et al., 2017). Such transitions are governed by a variety of environmental factors such as cloud top entrainment (Xiao et al., 2010), large-scale subsidence (Randall \& Suarez, 1984; Sundararajan \& Tjernström, 2000; Young et al., 2018), lower-tropospheric stability (Wood \& Bretherton, 2006), the ambient aerosol concentration (Xue et al., 2008; Wood et al., 2011), decoupling of the cloud layer from the surface (Wyant et al., 1997; Bretherton \& Wyant, 1997), or precipitation and drizzle formation (Savic-Jovcic \& Stevens, 2008; Wang \& Feingold, 2009). The latter has been found to be a key component of evaporative cooling, cold pool formation and a driver of cloud organization (Haerter et al., 2017; Haerter \& Schlemmer, 2018; Seifert \& Heus, 2013; Xue et al., 2008). Organized cloud structures have been frequently observed in the subtropical trade wind region (Bretherton \& Blossey, 2017; Wood \& Hartmann, 2006). In high latitudes they have so far been attributed to frontal features in low-pressure systems (Naud et al., 2016) or cold air outbreaks (Abel et al., 2017). 


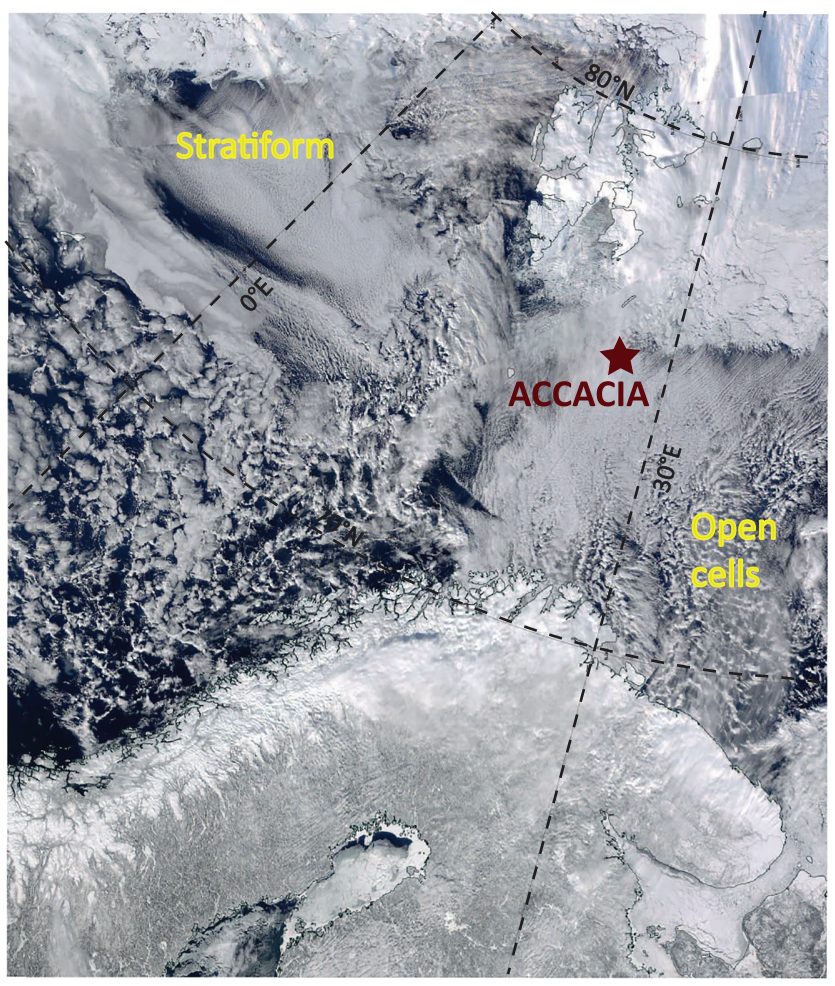

Figure 1. MODIS satellite image taken on 23 March 2013, the day of the simulated case study. Regimes of stratiform clouds and open-cell convection are visually identified. The brown star marks the location of the dropsonde release during the ACCACIA campaign. The satellite image was retrieved from NASA worldview.

Cloud types span a multitude of thermodynamic states. Clouds can either consist purely of ice crystals or water droplets or they can be mixed phase. Even though mixed-phase clouds (MPCs) are thermodynamically unstable, they occur worldwide, mainly in areas of deep convection (Rosenfeld \& Woodley, 2000), mountainous terrain (Lohmann et al., 2016), or the polar latitudes (Morrison et al., 2011; Shupe et al., 2006). While former analyses of cloud organization have been limited to warm clouds in the lower latitudes, there is visual evidence from satellite data that high-latitude MPCs may also organize into different morphological regimes, even far away from large-scale synoptic features (Figure 1). Although visually their organization appears similar to that observed in the subtropics, on a process level it might be hypothesized that the cloud ice phase impacts cloud cell growth and dissipation. Cloud ice increases precipitation (Field \& Heymsfield, 2015; Knight et al., 2002), which in turn is crucial for regime transitions and cloud dissipation (as shown for a cold air outbreak in model simulations by Abel et al., 2017). Hence, the ice phase may influence the spatial and temporal scales of organization. However, the detailed mechanisms driving organized cloud structures and the specific role of the different thermodynamic phases present in MPCs remain so far unexplored.

Here, we present a first analysis of MPC organization based on a case study in the European Arctic. We perform cloud-resolving model simulations for stratocumulus clouds observed during the Aerosol-Cloud Coupling and Climate Interactions in the Arctic (ACCACIA) campaign (Figure 1; Lloyd et al., 2015; Young et al., 2016). Roll clouds form in strong advection events of cold air masses over relatively warm surface temperatures. In the absence of horizontal wind, the precipitating clouds establish an open-cell organization instead. The horizontal wind was omitted in our experiments in order to provide a first assessment of the impact of ice formation on cloud field organization independently of large-scale drivers and the complexities of the sea ice-ocean interface. The open cells were classified in our simulations based on dynamical fields of the subcloud layer following Koren and Feingold (2013), with convective structures forming in narrow but strong circular updrafts (Figures 2 and S1 in the supporting information). The updraft structure is undeniably indicative of an open-cell organization, even through the cloud fraction is around $100 \%$. We contrast the simulated field of open-cell mixed-phase stratocumulus against a supercooled liquid cloud, where all ice cloud processes are disabled. This allows us to infer the importance of the ice phase in terms of cloud cell properties and regime transitions. 

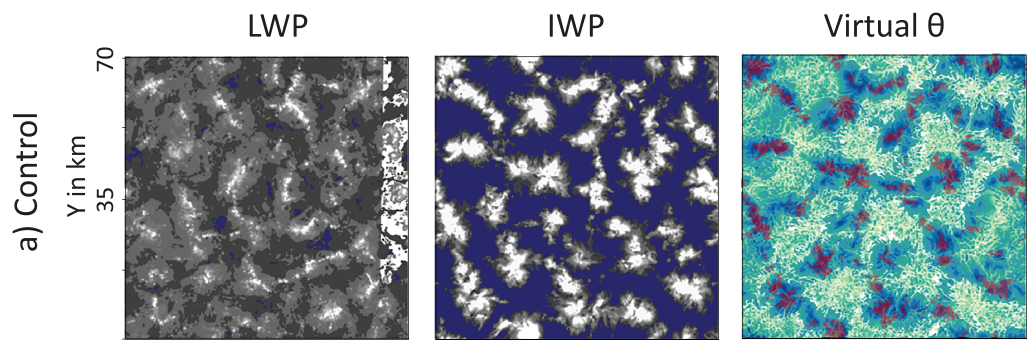

\section{Convergence}
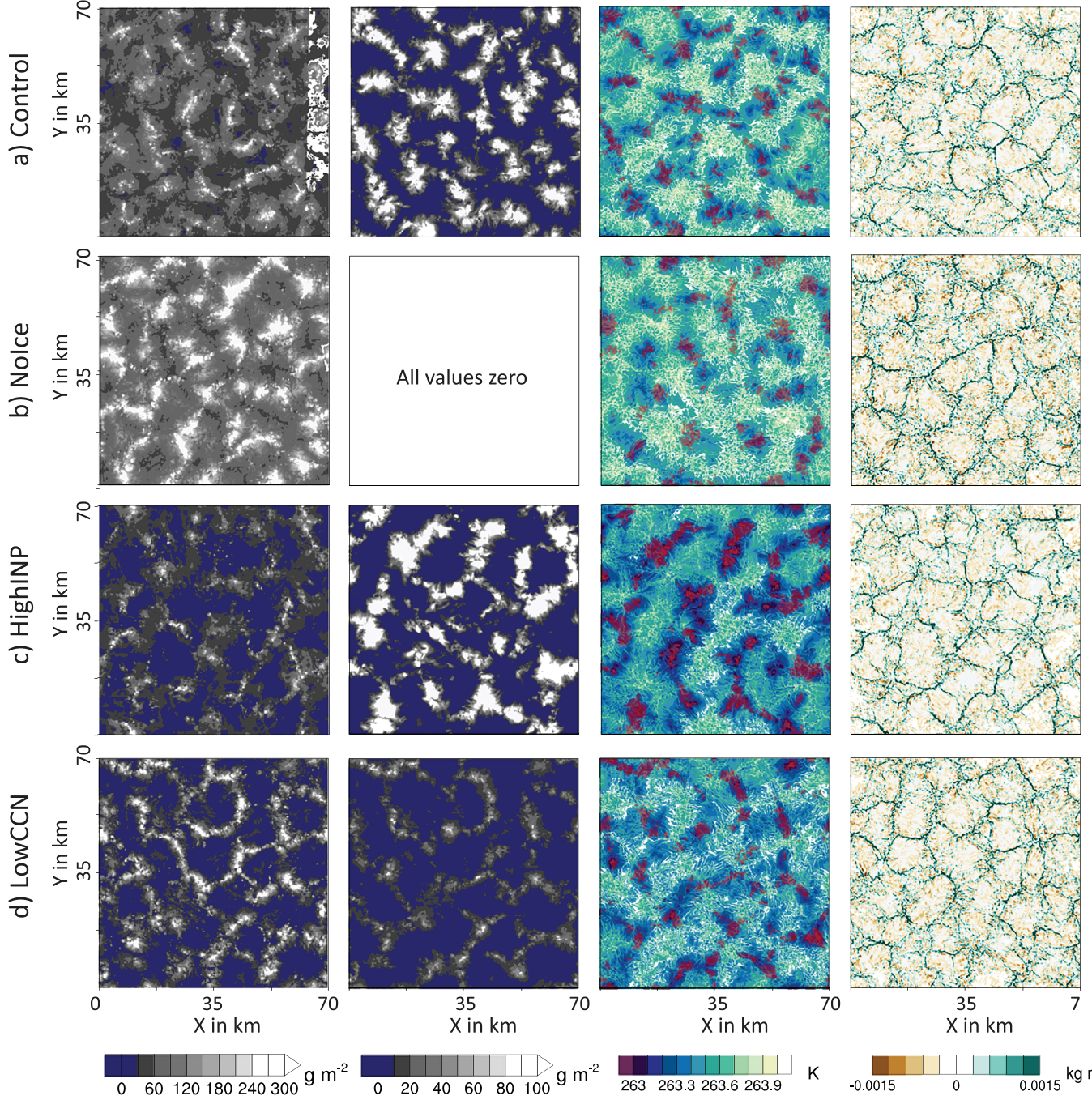

Figure 2. Instantaneous snapshots at 20-hr simulation time of LWP, IWP, surface virtual potential temperature (colors) and cloud base precipitation in $\mathrm{mm} / \mathrm{hr}$ exceeding the 85th percentile of the precipitation distribution (red shading), and vertically integrated moisture convergence below $200 \mathrm{~m}$ in the (a) Control, (b) NoIce, (c) HighINP, and (d) LowCCN simulations. LWP and IWP are calculated for in-cloud values (cloud liquid/ice water higher than 0.01 and $0.001 \mathrm{~g} / \mathrm{m}^{3}$, respectively) only.

\section{Model Description}

We perform cloud-resolving simulations using the Consortium for Small-scale Modeling (COSMO) model in its configuration for idealized large eddy simulations (Schättler et al., 2000). COSMO LES has been proven to simulate MPCs in the Arctic in reasonable accuracy (Possner et al., 2017; Eirund et al., 2019). Our setup is based on model experiments by Eirund et al. (2019); hence, we refer to this study and the supporting information for an extended model description (DeMott et al., 2015; Hallett \& Mossop, 1974; Nenes \& Seinfeld, 2003; Ralph et al., 2005; Ritter \& Geleyn, 1992). We simulate a single-layer stratocumulus case observed during the ACCACIA campaign on 23 March 2013 (Lloyd et al., 2015; Young et al., 2016). Our case is characterized by a well-pronounced single-temperature inversion at approximately 1,400 $\mathrm{m}$, covering a moist layer between 300 and 1,400 m (Figure S2; Young et al., 2016; Eirund et al., 2019). The simulations are initialized with a dropsonde profile measured during the campaign (Young et al., 2016). The domain covers a $70 \times 70 \mathrm{~km}^{2}$ large area around the location of the dropsonde release $\left(75^{\circ} \mathrm{N}, 24.5^{\circ} \mathrm{E}\right)$, with a horizontal resolution of $200 \mathrm{~m}$ and a variable vertical resolution of 20 to $50 \mathrm{~m}$ throughout the boundary layer and coarser resolution above cloud top. To allow for the formation of organized structures within the modeled domain, 
horizontal wind speeds are set to 0 during the simulation. To avoid any external influence on the boundary layer temperature, we simulate only nighttime conditions, that is, incoming shortwave radiation is set to 0 at any time. The cloud microphysical tendencies are parameterized following the Seifert and Beheng (2006) two-moment scheme. Cloud droplet activation is calculated from the ambient cloud condensation nuclei $(\mathrm{CCN})$ concentration, which is kept constant at a value of $100 \mathrm{~cm}^{-3}$ at every grid point, according to the observed cloud droplet number concentrations (Young et al., 2016). Throughout the simulations the CCN composition is assumed to be ammoniumbisulfate. Prognostic ice nucleating particles (INPs) available for immersion freezing are treated as in Possner et al. (2017). The INP concentration was initialized with $3.3 \mathrm{~L}^{-1}$, which is at the high end of estimated ice crystal number concentrations $\left(\mathrm{N}_{i c e}\right)$ in Young et al. (2016), but prevents an underestimation of $\mathrm{N}_{i c e}$ in the simulated clouds.

To investigate the importance of the ice phase on the organization of MPCs, we altered our Control simulation by omitting all ice processes in the NoIce simulation (implying that all clouds only contain supercooled liquid), similar to simulations in Stevens et al. (2018). To provide one scenario with intensified ice processes, we increased the INPs in the Control simulation by a factor of 4 (HighINP). Finally, we investigate the impact of a CCN-limited environment and decreased the $\mathrm{CCN}$ concentration from 100 to $20 \mathrm{~cm}^{-3}$ in LowCCN (Table S1).

\section{Results}

\subsection{Mechanisms of Organization in Arctic Mixed-Phase Stratocumulus}

Surface precipitation in Arctic boundary layer clouds typically occurs in the form of light precipitation (0.01-1 mm/day) and comprises liquid, but mostly solid precipitation (Eirund et al., 2019; Klein et al., 2009; Morrison et al., 2011; Possner et al., 2017; Shupe, 2011). Here we show that these light precipitation rates enforce cloud field organization also in Arctic MPCs (Figure 2a). The cloud field visualized in Figure 2 clearly features cellular structures evident as liquid and ice convective cells. These are accompanied by cold pools with a maximum of $0.8 \mathrm{~K}$ in regions of high cloud base precipitation (Figure 2a). Hence, the evaporation and sublimation of subcloud liquid and solid precipitation is sufficient to form (small) surface cold pools, which induce divergent flow in the cold pool centers and convergence at the cell edges (Figure 2a). This air mass flow leads to upward motion (Figure S1) and the convective cloud structures seen in Figure 2. At the boundary layer top the lifted cloud parcels are pushed out horizontally and the cloud detrains laterally. This open-cell cloud structure is maintained by a continuous cycle of evaporation/sublimation, cooling, lateral air mass movement, convergence, updrafts, and subsequent cloud formation.

\subsection{Cold Pool Intensification in Simulations Containing Cloud Ice}

To quantify the role of the ice phase within MPCs in contrast to supercooled liquid clouds, we compare the previously pictured mechanism in these two thermodynamic cloud regimes. For this purpose, we analyze boundary layer characteristics of the subcloud layer in the Control and NoIce simulations. As a consequence of ice formation within the Control simulation, LWP (defined as vertically integrated in-cloud rain and cloud liquid water) is reduced by $35 \mathrm{~g} / \mathrm{m}^{2}$ on average compared to NoIce (Figure 3a). The averaged IWP (in-cloud ice, snow, and graupel) is $26.3 \%$ of the LWP in Control (Figure 3b), which is within the range of Arctic MPCs (Eirund et al., 2019; Klein et al., 2009; Ovchinnikov et al., 2014; Possner et al., 2017; Stevens et al., 2018; Young et al., 2017). The presence of cloud ice does indeed increase the total cloud base precipitation in our Control simulation compared to NoIce in the spatial average $(0.70 \mathrm{~mm} / \mathrm{hr}$ in Control and $0.44 \mathrm{~mm} / \mathrm{hr}$ in NoIce; not shown) and in the spatial extremes, that is, grid points of cloud base precipitation exceeding the 85th percentile determined over the simulation domain $(2.4 \mathrm{~mm} / \mathrm{hr}$ in Control and 1.4 in NoIce; Figure 3f). Whereas all precipitation in NoIce is rain, $45.8 \%$ subcloud precipitation exceeding the 85 th percentile in Control is sedimenting ice, $42.4 \%$ snow, and $8.9 \%$ graupel, while rain is only $2.9 \%$.

As a result of increased cloud base precipitation rates, more precipitation sublimates and evaporates in Control (Figure $3 \mathrm{~g}$ ). This increased amount of sublimated and evaporated precipitation $(0.35 \mathrm{~mm} / \mathrm{hr}$ on average and $1.13 \mathrm{~mm} / \mathrm{hr}$ exceeding the 85th percentile) cools the subcloud layer through latent cooling on average by $0.14 \mathrm{~K} / \mathrm{hr}$ (Figure $3 \mathrm{~h}$ ). As expected from theory, cold pools form and spread near the surface, which are slightly stronger in Control (Figures 2a, 2b, and 3i). We did not find the increased amount of latent heat required for sublimation compared to evaporation to substantially impact subcloud layer cooling rates (supporting information and Figure S3). Therefore, changes in the subcloud layer cooling and cold pool strength are entirely attributable to changes in precipitation mass alone. In addition, we found that subcloud layer cooling and cold pool strength are substantially extenuated in a simulation where all precipitation and ice 

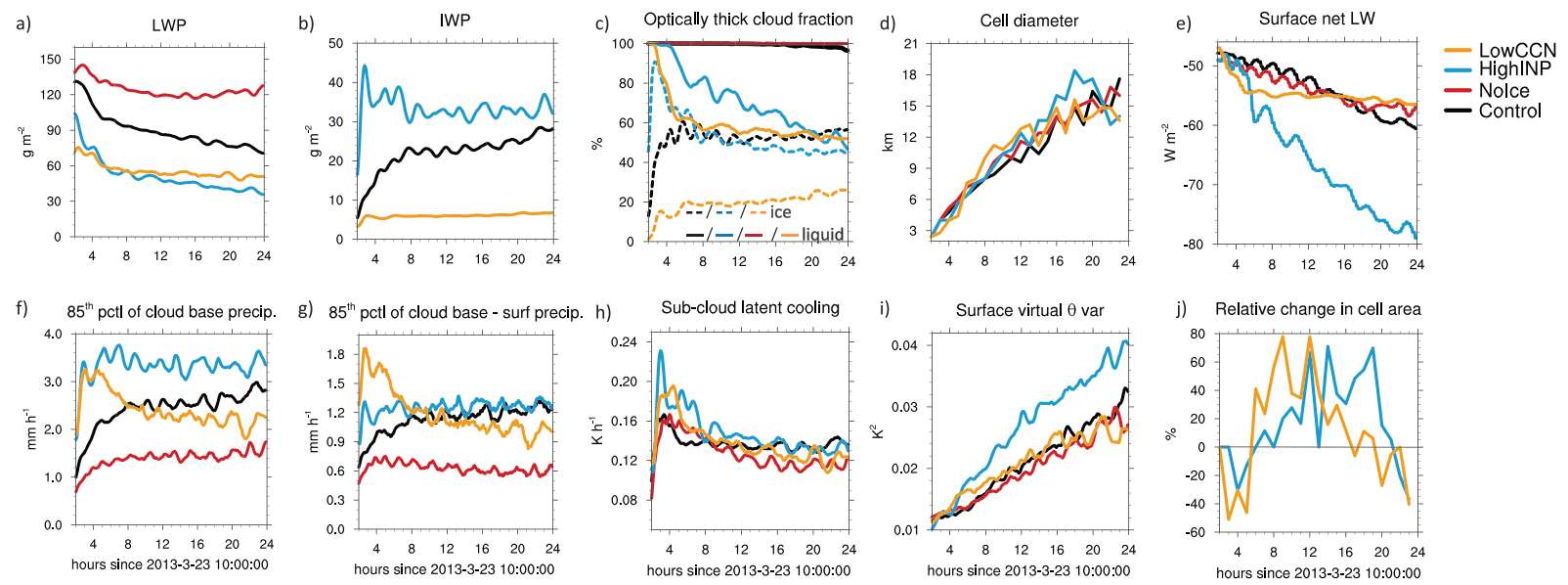

Figure 3. Temporal evolution of (a) LWP; (b) IWP; (c) liquid (solid lines) and ice (dashed lines) fraction of cloudy grid points exceeding LWP of $30 \mathrm{~g} / \mathrm{m}^{2}$ and IWP of $10 \mathrm{~g} / \mathrm{m}^{2}$ (corresponding to the blue colors in Figure 2); (d) cloud cell diameter calculated according to Haerter et al. (2017); (e) net surface longwave radiation; (f) cloud base precipitation exceeding the 85th percentile of the cloud base precipitation distribution; (g) evaporated precipitation between cloud base and the lowest model level, sampled at all points where the cloud base precipitation exceeded the 85th percentile of the cloud base precipitation distribution shown in (f); (h) mean subcloud layer latent cooling; (i) variance of the surface virtual potential temperature; and (j) relative change of cell area in HighINP and LowCCN with respect to Control. Cloud base for each simulation has been estimated as the lowest model level, where $>1 \%$ of all grid points contain cloud liquid water $>0.01 \mathrm{~g} / \mathrm{m}^{3}$.

processes generally are inhibited (supporting information and Figure S4). In the absence of subcloud cooling and cold pool formation no cloud organization is established (Figure S4). This allows us to conclude that precipitation intensity is the sole driver of MPC organization in this case.

To quantify the spatial scales of cloud organization, we apply the two-point correlation method of moisture convergence as introduced by Haerter et al. (2017) and described in more detail in the supporting information. The result provides a measure of the field mean cell diameter (Figure 3d), which was further averaged hourly for all simulations. Generally, the individual cells grow with time (as also seen in simulations by Wang \& Feingold, 2009; Haerter et al., 2017). However, differences in cell size are at most on the order of 2 $\mathrm{km}$, which implies only a small impact of cloud ice on cell size for IWP $\leq 30 \mathrm{~g} / \mathrm{m}^{2}$.

As INP concentrations in the Arctic can vary by up to 4 orders of magnitudes and may remain elevated especially during Arctic haze conditions in spring (McFarquhar et al., 2011), we increased INP concentrations by a factor of 4 up to $12 \mathrm{~L}^{-1}$ in our HighINP simulation. Simulated mean $\mathrm{N}_{\text {ice }}$ increase but remain below $2 \mathrm{~L}^{-1}$ (Figure S5). Consistent with a Twomey effect for ice crystals (Kärcher \& Lohmann, 2003; Twomey, 1974), the ice crystal radius decreases (Figure S5). Averaged LWP reduces to $51.3 \mathrm{~g} / \mathrm{m}^{2}$ and IWP increases to $33.6 \mathrm{~g} / \mathrm{m}^{2}$ (Figures 3a and $3 b$ ), such that IWP is generally $\geq 50 \%$ of LWP in HighINP. This response to an increase in INPs is consistent with previous studies (Eirund et al., 2019; Possner et al., 2017; Young et al., 2017; Young et al., 2018) and still within a realistic range for the Arctic environment (Shupe et al., 2008). Despite the smaller ice crystals, the 85th percentile of cloud base precipitation in HighINP is increased (Figure 3f). Most of this precipitation is snow (53.4\%), which forms through accretion of several small ice crystals. The total mass of precipitation evaporated/sublimated in the subcloud layer is higher in the HighINP simulation, especially within the first $12 \mathrm{hr}$ (Figure 3g). This strongly cools the subcloud layer in the first hours (Figure 3h). As a result, cold pool strength is substantially increased in HighINP compared to Control and NoIce (Figures 2c and 3i). To compensate for the strong surface density gradient, cloud cells are forced to expand laterally, which results in larger cloud cells in HighINP (Figures $2 \mathrm{c}$ and $3 \mathrm{~d}$ ). These larger cloud cells imply an up to $70 \%$ increase in cloud cell area in HighINP relative to Control (Figure 3j). During cell growth, the fraction of optically thick liquid and ice cloud structures decreases in HighINP, the stratocumulus deck thins, and the organized structures start to break up (Figures $2 \mathrm{c}$ and $3 \mathrm{c}$ ). Directly coupled to the altered cloud morphology is net surface longwave (LW) radiation (Figure 3e). Specifically in HighINP, where the optically thick cloud cover decreases most rapidly, the outgoing LW radiation at the surface increases with time. In the absence of incoming solar radiation this implies a strong surface cooling in response to the thinning and breakup of the organized cloud structures. 
Hence, we conclude that for sufficiently high IWP (on the order of a 2:1 LWP:IWP ratio), cloud ice processes substantially contribute to cold pool strength and the spatial extent of MPC organization, and can consequently impact the radiative balance at the surface.

\subsection{Cloud Organization in an Aerosol-Limited Regime}

Similarly to INPs, CCN concentrations in the Arctic can vary quite dramatically, from only a few per cubic centimeter (Tjernström et al., 2014) up to a few hundred during Arctic haze (McFarquhar et al., 2011) or thousands in ship exhaust plumes (Hobbs et al., 2000). A low availability of CCN is leading to fewer and larger cloud droplets according to the Twomey effect and thus potentially increased precipitation rates (Albrecht, 1989). In our LowCCN simulation we test this mechanism and its relevance for cloud organization by lowering the ambient $\mathrm{CCN}$ concentration by a factor of 5 from 100 to $20 \mathrm{~cm}^{-3}$. As a result of fewer CCN, LWP and IWP are reduced (Figures $3 \mathrm{a}$ and $3 \mathrm{~b}$ ), which agrees with previous results of an increased (decreased) LWP and IWP for increased (decreased) CCN concentrations, respectively (Eirund et al., 2019; Possner et al., 2017; Stevens et al., 2018). In addition, cloud droplets are larger (15 $\mu \mathrm{m}$ in LowCCN compared to $10 \mu \mathrm{m}$ in Control; not shown), as expected from the Twomey effect.

Decreasing the background $\mathrm{CCN}$ concentration has a similar effect on the relative change in cell area as the intensification of ice phase processes. In the simulation with lower $\mathrm{CCN}$, liquid precipitation rates in the cell wall updrafts increase (Figure 3f). Increased levels of subcloud evaporation due to the elevated precipitation mass flux cool the subcloud layer and increase the cold pool strength (Figures $3 \mathrm{f}-3 \mathrm{i}$ ). Similarly to HighINP, the cloud cells grow, the stratocumulus thins, and the net surface LW radiation decreases in LowCCN (Figures 3c-3e).

However, increased rates of precipitation are of shorter duration in LowCCN as opposed to HighINP. After the first $8 \mathrm{hr}$ of the simulation, the high cloud base precipitation rates are decreased in $\operatorname{Low} C C N(2.3 \mathrm{~mm} / \mathrm{hr})$ compared to Control $(2.6 \mathrm{~mm} / \mathrm{hr}$; Figure $3 \mathrm{f})$. This difference is mainly driven by the ice phase, which is highly reduced in LowCCN. The initially growing ice phase in Control contributes to high cloud base precipitation rates only once IWP has stabilized around $20 \mathrm{~g} / \mathrm{m}^{2}$ after $8-\mathrm{hr}$ simulation time. The importance of the ice phase for precipitation formation is further illustrated by the contributions of the different hydrometeors to cloud base precipitation. Whereas sedimenting ice, snow, and graupel contribute $97.1 \%$ to cloud base precipitation exceeding the 85th percentile in Control, the ice phase accounts for only $35.8 \%$ of high precipitation in LowCCN. Consequently, after the first $8 \mathrm{hr}$, evaporated/sublimated precipitation in LowCCN is reduced compared to Control but increased compared to NoIce (Figure 3g). As a result, boundary layer cooling and cold pool strength is qualitatively similar in the LowCCN and Control simulations (Figure 3i) and the change in cell size in LowCCN relative to Control decreases to below $20 \%$ after $12 \mathrm{hr}$.

These experiments are supporting the finding that precipitation intensity is the key driver determining the spatial scale of open-cell organization. The phase of precipitation does not seem to impact the short-term change in cloud cell dimension. However, we find that altered precipitation rates and the resulting cloud and radiation changes persist over longer time periods if generated through ice phase processes rather than a depletion in CCN.

\section{Discussion and Conclusions}

This study provides a first insight into processes controlling mixed-phase stratocumulus organization as can be observed in high latitudes. We showed that the same mechanisms are at play in precipitating polar MPCs as have been observed in the subtropics. Consequently, similar measures to quantify the organization scales can be applied (e.g., Haerter et al., 2017).

Generally, our results support findings by Abel et al. (2017) in the sense that ice processes induce a cloud deck thinning and a breakup in organization. Conceptually, we show that cloud ice strengthens subcloud precipitation through sedimenting snow, ice, and graupel (as summarized in Figure 4). These locally intense precipitation events induce cold pools at the surface of up to $1 \mathrm{~K}$ in HighINP. For larger IWP we find stronger cold pools and larger cloud cells in our simulations. Differences in cloud cell size are visible for a LWP:IWP ratio of approximately $2: 1$. The thinning and breakup of the open-cell structures lead to a difference in net surface LW between HighINP and Control of $11.9 \mathrm{~W} / \mathrm{m}^{2}$, which implies $18.1 \%$ stronger cooling in HighINP than in Control. The enhanced outgoing surface radiation may have considerable impact on the surface radiative balance in the Arctic during, for example, polar winter. The illustrated process could potentially 
a) supercooled liquid clouds

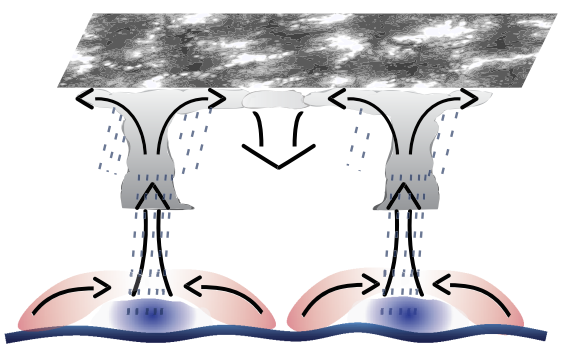

b) mixed-phase clouds

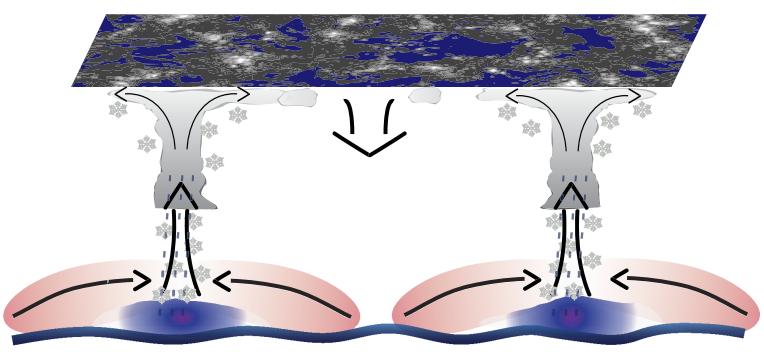

Figure 4. Schematic summary of stratocumulus organization in (a) supercooled liquid clouds without ice processes and (b) MPCs with an LWP:IWP ratio of 2:1. The cloud top view is the simulated LWP in the NoIce and HighINP simulations as shown in Figures $2 b$ and $2 c$. In MPCs increased precipitation at cloud base via the ice phase induces strong (up to $1 \mathrm{~K}$ ) cold pools at the surface (blue colors), which spread, converge, and lead to upward motion of the warmer surrounding air (upward arrows and red colors), forming convective clouds and broad downdraft region (downward arrows). Due to the stronger and laterally expanding cold pools, cloud cells are larger. Ice and liquid water are constrained to relatively narrow convective towers, with weak lateral detrainment of cloud ice. In supercooled liquid clouds, cloud base precipitation is reduced as compared to MPCs which results in relatively weaker cold pools and a thicker stratocumulus cloud deck in the absence of cloud ice.

be reinforced at temperatures favorable for secondary ice formation (Sotiropoulou et al., 2019), where even higher ice crystal concentrations than simulated in HighINP may further increase precipitation and induce a more rapid stratocumulus breakup (Abel et al., 2017). Nevertheless, open questions remain. Further work may want to investigate how these results might change with large-scale or surface forcing, which have been shown to impact midlatitude convective organization (Moseley et al., 2016). In addition, a strong greenhouse gas forcing might lead to a stratocumulus breakup as recently shown by Schneider et al. (2019).

Uncertainty still remains in terms of the role of aerosols available for cloud droplet formation in cloud organization. When limiting the background $\mathrm{CCN}$ from 100 to $20 \mathrm{~cm}^{-3}$, we find a shorter-term impact on cold pool strength and cloud cell size as compared to ice phase changes. Miltenberger et al. (2018a) found substantially larger cloud cells in simulations of summertime deep convective clouds with higher aerosol concentrations compared to a low aerosol environment. In addition, these aerosol-induced changes were statistically significant compared to the uncertainty introduced by a meteorological ensemble (Miltenberger et al., 2018b). However, their aerosol concentrations are much larger than observed for the Arctic environment and in deep convective clouds latent heating from condensation and turbulence are stronger than in shallow stratocumulus. Also in the simulations conducted by Miltenberger et al. (2018a), the total aerosol concentration was changed, with no individual increase in CCN or INP concentrations. Generally, our results agree with their study, but we find a shorter-term response in cloud base precipitation intensity and cell size induced by CCN concentration changes as opposed to ice phase processes. Similarly, Xue et al. (2008) found that there is an effect of aerosol concentration on warm-phase trade wind shallow cumulus clouds, but of opposite sign as in Miltenberger et al. (2018a); that is, they found smaller but more numerous clouds for increased background aerosol concentrations. As observations have indicated an aerosol influence on the cloud regime (Wood et al., 2011), this topic deserves further attention in future studies. We suggest to address the role of CCN and INP perturbations on different MPC regimes (e.g., purely convective, open and closed-cell structures) in future studies. Moreover, the impact of prognostic CCN, where collision-coalescence and sedimentation processes can clean out the boundary layer (Abel et al., 2017; Wood et al., 2008) should be investigated in more detail.

\section{References}

Abel, S. J., Boutle, I. A., Waite, K., Fox, S., Brown, P. R. A., Cotton, R., et al. (2017). The role of precipitation in controlling the transition from stratocumulus to cumulus clouds in a Northern Hemisphere cold-air outbreak. Journal of the Atmospheric Sciences, 74(7), $2293-2314$. https://doi.org/10.1175/JAS-D-16-0362.1

Albrecht, B. A. (1989). Aerosols, cloud microphysics, and fractional cloudiness. Science, 245(4923), 1227-1230. https://doi.org/10.1126/ science.245.4923.1227

Bretherton, C. S., \& Blossey, P. N. (2017). Understanding mesoscale aggregation of shallow cumulus convection using large-eddy simulation. Journal of Advances in Modeling Earth Systems, 9, 2798-2821. https://doi.org/10.1002/2017MS000981

Bretherton, C. S., \& Wyant, M. C. (1997). Moisture transport, lower-tropospheric stability, and decoupling of cloud-topped boundary layers. Journal of the Atmospheric Sciences, 54(1), 148-167. https://doi.org/10.1175/1520-0469(1997)054h0148:MTLTSAi2.0.CO;2 
DeMott, P. J., Prenni, A. J., McMeeking, G. R., Kreidenweis, S. M., Petters, M. D., Twohy, C. H., et al. (2015). Integrating laboratory and field data to quantify the immersion freezing ice nucleation activity of mineral dust particles. Atmospheric Chemistry and Physics, 15(1), 393-409. https://doi.org/10.5194/acp-15-393-2015

Eirund, G. K. (2019). Eirund_et_al_2019_MPCorganization. https://data.iac.ethz.ch/Eirund_et_al_2019_MPCorganization/, last access: 19 October 2019.

Eirund, G. K., Possner, A., \& Lohmann, U. (2019). Response of Arctic mixed-phase clouds to aerosol perturbations under different surface forcings. Atmospheric Chemistry and Physics, 19, 9847-9864. https://doi.org/10.5194/acp-19-9847-2019

Field, P. R., \& Heymsfield, A. J. (2015). Importance of snow to global precipitation. Geophysical Research Letters, 42, 9512-9520. https:// doi.org/10.1002/2015GL065497

Haerter, J. O., Berg, P., \& Moseley, C. (2017). Precipitation onset as the temporal reference in convective self-organization. Geophysical Research Letters, 44, 6450-6459. https://doi.org/10.1002/2017GL073342

Haerter, J. O., \& Schlemmer, L. (2018). Intensified cold pool dynamics under stronger surface heating. Geophysical Research Letters, 45(12), 6299-6310. https://doi.org/10.1029/2017GL076874

Hallett, J., \& Mossop, S. C. (1974). Production of secondary ice particles during the riming process. Nature, 26-28.

Hobbs, P. V, Garrett, T. J., Ferek, R. J, Strader, S. R, Hegg, D. A, Frick, G. M, et al. (2000). Emissions from ships with respect to their effects on clouds. Journal of the Atmospheric Sciences, 57(16), 2570-2590. https://doi.org/10.1175/1520-0469(2000)057h2570:EFSWRTi2.0.CO;2

Kärcher, B., \& Lohmann, U. (2003). A parameterization of cirrus cloud formation: Heterogeneous freezing. Journal of Geophysical Research, 108(D14), 4402. https://doi.org/10.1029/2002jd003220

Klein, S. A., McCoy, R. B., \& Morrison, H. (2009). Intercomparison of model simulations of mixed-phase clouds observed during the ARM Mixed-Phase Arctic Cloud Experiment. I: Single-layer cloud. Quarterly Journal of the Royal Meteorological Society, 133(October), 937-948. https://doi.org/10.1002/qj

Knight, C. A., Knight, N. C., Dye, J. E., \& Toutenhoofd, V. (2002). The mechanism of precipitation formation in Northeastern Colorado cumulus: I. Observations of the precipitation itself. Journal Atmospheric Research, 31(8), 2142-2147. https://doi.org/10.1175/ 1520-0469(1974)031h2142:tmopfi2.0.co;2

Koren, I., \& Feingold, G. (2013). Adaptive behavior of marine cellular clouds. Scientific Reports, 3, 1-5. https://doi.org/10.1038/srep02507

Lloyd, G., Choularton, T. W., Bower, K. N., Crosier, J., Jones, H., Dorsey, J. R., et al. (2015). Observations and comparisons of cloud microphysical properties in spring and summertime Arctic stratocumulus clouds during the ACCACIA campaign. Atmospheric Chemistry and Physics, 15(7), 3719-3737. https://doi.org/10.5194/acp-15-3719-2015

Lohmann, U., Henneberger, J., \& Henneberg, O. (2016). Persistence of orographic mixed-phase clouds. Geophysical Research Letters, 43 , 1-8. https://doi.org/10.1002/2016GL071036

McCoy, I. L., Wood, R., \& Fletcher, J. K. (2017). Identifying meteorological controls on open and closed mesoscale cellular convection associated with marine cold air outbreaks. Journal of Geophysical Research: Atmospheres, 122, 11,678-11,702. https://doi.org/10.1002/ 2017JD027031

McFarquhar, G. M., Ghan, S., Verlinde, J., Korolev, A., Strapp, J. W., Schmid, B., et al. (2011). Indirect and semi-direct aerosol campaign: The impact of Arctic aerosols on clouds. Bulletin of the American Meteorological Society, 92(2), 183-201. https://doi.org/10.1175/ 2010BAMS2935.1

Miltenberger, A. K., Field, P. R., Hill, A. A., Rosenberg, P., Shipway, B. J., Wilkinson, J. M., et al. (2018a). Aerosol-cloud interactions in mixed phase convective clouds. Part 1: Aerosol perturbations. Atmospheric Chemistry and Physics, 18(14), 3119-3145. https://doi.org/ 10.5194/acp-2017-788

Miltenberger, A. K., Field, P. R., Hill, A. A., Shipway, B. J., \& Wilkinson, J. M. (2018b). Aerosol-cloud interactions in mixed-phase convective clouds?Part 2: Meteorological ensemble. Atmospheric Chemistry and Physics, 18(14), 10,593-10,613. https://doi.org/10.5194/ acp-18-10593-2018

Morrison, H., de Boer, G., Feingold, G., Harrington, J., Shupe, M. D., \& Sulia, K. (2011). Resilience of persistent Arctic mixed-phase clouds. Nature Geoscience, 5(1), 11-17. https://doi.org/10.1038/ngeo1332

Moseley, C., Hohenegger, C., Berg, P., \& Haerter, J. O. (2016). Intensification of convective extremes driven by cloud-cloud interaction. Nature Geoscience, 9(10), 748-752. https://doi.org/10.1038/ngeo2789

Naud, C. M., Booth, J. F., \& Del Genio, A. D. (2016). The relationship between boundary layer stability and cloud cover in the post-cold-frontal region. Journal Climate, 29(22), 8129-8149. https://doi.org/10.1175/JCLI-D-15-0700.1

Nenes, A., \& Seinfeld, J. H. (2003). Parameterization of cloud droplet formation in global climate models. Journal of Geophysical Research, 108(D14), 4415. https://doi.org/10.1029/2002JD002911

Ovchinnikov, M., Ackerman, A. S., Avramov, A., Cheng, A., Fan, J., Fridlind, A. M., et al. (2014). Intercomparison of large-eddy simulations of Arctic mixed-phase clouds: Importance of ice size distribution assumptions. Journal of Advances in Modeling Earth Systems, 6, 513-526. https://doi.org/10.1002/2013MS000282

Possner, A., Ekman, A. M. L., \& Lohmann, U. (2017). Cloud response and feedback processes in stratiform mixed-phase clouds perturbed by ship exhaust. Geophysical Research Letters, 44, 1964-1972. https://doi.org/10.1002/2016GL071358

Ralph, F. M, Neiman, P. J., \& Rotunno, R. (2005). Dropsonde observations in low-level jets over the Northeastern Pacific Ocean from CALJET-1998 and PACJET-2001: Mean vertical-profile and atmospheric-river characteristics. Monthly Weather Review, 133, 889-910.

Randall, D. A., \& Suarez, M. J. (1984). On the dynamics of stratocumulus formation and dissipation. Journal of the Atmospheric Sciences, 41(20), 3052-3057.

Ritter, B., \& Geleyn, J.-F. (1992). A comprehensive radiation scheme for numerical weather prediction models with potential applications in climate simulations. Monthly Weather Review, 120(2), 303-325. https://doi.org/10.1175/1520-0493(1992)120h0303:ACRSFNi2.0.CO;2

Rosenfeld, D., \& Woodley, W. L. (2000). Deep convective clouds with sustained supercooled liquid water down to -37.5C. Nature, 405(6785), 440-442.

Savic-Jovcic, V., \& Stevens, B. (2008). The structure and mesoscale organization of precipitating stratocumulus. Journal of the Atmospheric Sciences, 65(5), 1587-1605. https://doi.org/10.1175/2007JAS2456.1

Schättler, U., Doms, G., \& Steppele, J. (2000). Requirements and problems in parallel model development at DWD. Scientific Programming, $8(1), 13-22$

Schneider, T., Kaul, C. M., \& Pressel, K. G. (2019). Supplement: Possible climate transitions from breakup of stratocumulus decks under greenhouse warming. Nature Geoscience, 12(3), 164-168. https://doi.org/10.1038/s41561-019-0310-1

Seifert, A., \& Beheng, K. D. (2006). A two-moment cloud microphysics parameterization for mixed-phase clouds. Part 1: Model description. Meteorology and Atmospheric Physics, 92(1-2), 45-66. https://doi.org/10.1007/s00703-005-0112-4

Seifert, A., \& Heus, T. (2013). Large-eddy simulation of organized precipitating trade wind cumulus clouds. Atmospheric Chemistry and Physics, 13(11), 5631-5645. https://doi.org/10.5194/acp-13-5631-2013 
Shupe, M. D. (2011). Clouds at arctic atmospheric observatories. Part II: Thermodynamic phase characteristics. Journal of Applied Meteorology and Climatology, 50(3), 645-661. https://doi.org/10.1175/2010JAMC2468.1

Shupe, M. D., Daniel, J. S., De Boer, G., Eloranta, E. W., Kollias, P., Long, C. N., et al. (2008). A focus on mixed-phase clouds. Bulletin of the American Meteorological Society, 89(10), 1549-1562. https://doi.org/10.1175/2008BAMS2378.1

Shupe, M. D., Matrosov, S. Y., \& Uttal, T. (2006). Arctic mixed-phase cloud properties derived from surface-based sensors at SHEBA. Journal of the Atmospheric Sciences, 63(2), 697-711. https://doi.org/10.1175/JAS3659.1

Sotiropoulou, G., Sullivan, S., Savre, J., Lloyd, G., Lachlan-Cope, T., Ekmann, A. M. L., \& Nenes, A. (2019). The impact of secondary ice production on Arctic stratocumulus. Atmospheric Chemistry and Physics, Discussions, 1-32.

Stevens, R. G., Loewe, K., Dearden, C., Dimitrelos, A., Possner, A., Eirund, G. K., et al. (2018). A model intercomparison of CCN-limited tenuous clouds in the high Arctic. Atmospheric Chemistry and Physics, 18, 11,041-11,071. https://doi.org/10.5194/acp-2017-1128

Sundararajan, R., \& Tjernström, M. (2000). Observations and simulations of a non-stationary coastal atmospheric boundary layer. Quarterly Journal of the Royal Meteorological Society, 126(563), 445-476. https://doi.org/10.1256/smsqj.56304

Tjernström, M., Leck, C., Birch, C. E., Bottenheim, J. W., Brooks, B. J., Brooks, I. M., et al. (2014). The Arctic Summer Cloud Ocean Study (ASCOS): Overview and experimental design. Atmospheric Chemistry and Physics, 14(6), 2823-2869. https://doi.org/10.5194/ acp-14-2823-2014

Twomey, S. (1974). Pollution and the planetary albedo. Atmospheric Environment, 8, 1251-1256. https://doi.org/10.1016/j.atmosenv.2007. 10.062

Wang, H., \& Feingold, G. (2009). Modeling mesoscale cellular structures and drizzle in marine stratocumulus. Part I: Impact of drizzle on the formation and evolution of open cells. Journal of the Atmospheric Sciences, 66(11), 3237-3256. https://doi.org/10.1175/2009JAS3022.1

Wood, R. (2012). Stratocumulus clouds. Monthly Weather Review, 140(8), 2373-2423. https://doi.org/10.1175/MWR-D-11-00121.1

Wood, R., \& Bretherton, C. S. (2006). On the relationship between stratiform low cloud cover and lower-tropospheric stability. Journal of Climate, 19(24), 6425-6432. https://doi.org/10.1175/JCLI3988.1

Wood, R., Bretherton, C. S., Leon, D., Clarke, A. D., Zuidema, P., Allen, G., \& Coe, H. (2011). An aircraft case study of the spatial transition from closed to open mesoscale cellular convection over the Southeast Pacific. Atmospheric Chemistry and Physics, 11(5), 2341-2370. https://doi.org/10.5194/acp-11-2341-2011

Wood, R., Comstock, K. K., Bretherton, C. S., Cornish, C., Tomlinson, J., Collins, D. R., \& Fairall, C. (2008). Open cellular structure in marine stratocumulus sheets. Journal of Geophysical Research, 113(12), D12207. https://doi.org/10.1029/2007JD009371

Wood, R., \& Hartmann, D. L. (2006). Spatial variability of liquid water path in marine low cloud: The importance of mesoscale cellular convection. Journal Climate, 19(9), 1748-1764. https://doi.org/10.1175/JCLI3702.1

Wyant, M. C., Bretherton, C. S., Rand, H. A., \& Stevens, D. E. (1997). Numerical simulations and a conceptual model of the stratocumulus to trade cumulus transition. Journal of the Atmospheric Sciences, 54(1), 168-192. https://doi.org/10.1175/1520-0469(1997)054h0168 NSAACMi2.0.CO;2

Xiao, H., Wu, C. M., \& Mechoso, C. R. (2010). Buoyancy reversal, decoupling and the transition from stratocumulus to shallow cumulus topped marine boundary layers. Climate Dynamics, 37(5), 971-984. https://doi.org/10.1007/s00382-010-0882-3

Xue, H., Feingold, G., \& Stevens, B. (2008). Aerosol effects on clouds, precipitation, and the organization of shallow cumulus convection. Journal of the Atmospheric Sciences, 65(2), 392-406. https://doi.org/10.1175/2007JAS2428.1

Young, G., Connolly, P. J., Dearden, C., \& Choularton, T. W. (2018). Relating large-scale subsidence to convection development in Arctic mixed-phase marine stratocumulus. Atmospheric Chemistry and Physics, 18(3), 1475-1494. https://doi.org/10.5194/acp-18-1475-2018

Young, G., Connolly, P. J., Jones, H. M., \& Choularton, T. W. (2017). Microphysical sensitivity of coupled springtime Arctic stratocumulus to modelled primary ice over the ice pack, marginal ice, and ocean. Atmospheric Chemistry and Physics, 17(6), 4209-4227. https://doi. org/10.5194/acp-17-4209-2017

Young, G, Jones, HM, Choularton, TW, Crosier, J., Bower, K. N., Gallagher, M. W., et al. (2016). Observed microphysical changes in Arctic mixed-phase clouds when transitioning from sea ice to open ocean. Atmospheric Chemistry and Physics, 16, 13,945-13,967. https://doi. org/10.5194/acp-2016-409 